日心第74回大会 (2010)

第1日 9月20日（月） $12: 30 \sim 14: 30 \quad$ C102

\title{
WS024「自己」の心理学研究に脳マッピングは役立つか？ 一心理学諸領域からの懐疑と期待
}

\begin{tabular}{|c|c|c|}
\hline 企 画 者 & 東北大学 & 杉浦 \\
\hline 司 会 者 & 富山大学 & 佐藤 \\
\hline 話題提供者 & 東北大学 & 杉浦 \\
\hline 舌題提供者 & (独行) 国立長寿医療研究センター研究所 & 宮腰 \\
\hline 題提供者 & 玉川大学 & 宮嵪美智子 \\
\hline 星供者 & 東海大学 & 由佳 \\
\hline 定討論者 & 京都大学 & 反倉 昭 \\
\hline
\end{tabular}

概 要

近年、「自己」の神経基盤について、機能的磁気共鳴画像法（fMRI）を用いた脳マッピング研究が華やかで ある。「自己」特異的（vs. 他者）な活動を示す脳領域を整理すると、「自己」概念は身体的自己（右頭頂葉・ 前頭葉）、個人的自己（頭頂・側頭接合部）、社会的自己（前頭前野内側）の 3 つに分類できる、と企画者は 考える。このように、活動領域の異同によって「自己」概念を整理する妥当性や、その成果が脳科学以外の 「自己」心理学領域でもつ意味について、様々な懁疑と期待がある。本ワークショップでは、まず企画者が

「自己」の脳マッピング研究の方法・現状と、独自の「自己」分類モデルについて概説し、これに対して 3 名の話題提供者が脳波を用いた生理心理学、発達心理学、社会心理学の立場から問題提起を行う。これに端 を発した討議から、fMRI を用いた「自己」脳マッピング研究の限界・課題・可能性について視野を拡大・共 有することを目的とする。 